\title{
Does the More Social Media Usage Good Academic Grade? Meta-Analysis
}

\author{
M N Ghufron ${ }^{1}$, K R Azmi ${ }^{2}$ \\ IAIN Kudus, Kudus, Jawa Tengah, Indonesia ${ }^{1,2}$ \\ \{emnurghufron78@iainkudus.ac.id¹, rofiazmi@iainkudus.ac.id²\}
}

\begin{abstract}
This study was conducted to test the relationship of social media usage on students' academic grades. This research was conducted using a meta-analysis. It specifically regarding the correlation between social media usage and academic grade. This study aims to conclude, integrate, and interpret data collected from previous research. The data used in this research must be the same construction and correlation patterns so that it can be compared between the results with another research. The quantitative review included 13 studies out of 10 articles containing a combined sample of about 4523 . The analysis was carried out by correcting sampling and measurement errors. The analysis shows that social media users have a correlation with academic grade. The results showed the use of social media was identified as a predictor of academic grade.
\end{abstract}

Keywords: social media usage, academic grade, and meta-analysis

\section{Introduction}

Social media starts when an individual starts communicating with others. Social means human society because the interference of people and media is an expressway. Once, mostly, the format of social networking or media were not digital. This condition encouraged inventors to create one application that generated inventions. Therefore, social networking or media is one of the most popular inventions and widely used technology nowadays. Social media is defined as "technology that makes social communication be easy and allows discussion among participants". Social media means network-based mobile applications that allow individuals or organizations to create, communicate, and share material.

Students are creators and media users. Because of the Internet and social web including Facebook, Twitter, blogs, smartphones, and text messages, they are getting alive in the world where information is the access to communication technology. For example, in 2010 a report showed about $73 \%$ of American teenagers used sites of social network and $75 \%$ owned cellphones. Not all students have the ability to use social media as well as understand, be critical and be able to evaluate new forms of information effectively and in making smart decisions about the quality and use [1].

Sudha and Kavitha [2] found that using more social media will be a problem with student learning outcomes. In fact, most school members are aware that social networking sites have bad impact on student learning outcomes rather than good impact, due to the lack of smart awareness between students and teacher for the appropriate use such as related to educational 
interests. In contrast to Sudha and Kavitha, Helou [3] revealed that the students in Malaysia agreed that social media sites had a positive impact on students' learning performance. While Raut and Patil [4] also found that the use of social networking has a good effect on society such as politics, economy, and education.

Social media has been used comprehensively. The user profiles of Facebook let users communicate information to others, realize and maintain relationship and build others to take part in the community among sites such as the origin of schools, or other communities. Recently, social media has been used to connect teachers or lecturers to students at a school or college institution [5]. This will turn to have pressure on schools like teachers and students to use social networks in the classroom and outside the classroom. Social media has advantages for schools or colleges because teachers or school members can connect with students at any time.

\section{Literature Review}

In the last few years, there have been many studies that have tried to find out the correlation between social networks and various academic activities. The study conducted by Madge, Meek, Wellens, and Hooley [6] at a university in the UK showed that Facebook and the learning outcomes of students had a negative correlation. Meanwhile, Pasek, More and Hargittai [7] found that social media like Facebook has a good impact on student achievement. According to his research, students with good achievement often use Facebook. Lenhart's research results [8] , found that the most popular online users were social networks in the 25-year age group and the ratio of students decreased or for adults less than 55 years.

Kim, Yun dan Yoon [9] stated that international class students are supported by Internet and social media. Instead focusing on building and maintaining social relationship, the main purpose of these students is to fulfill the academic needs. Lin [10] focused on the studies carried out mainly on the results of Facebook, which is used by the international class in the United States, found that the use of Facebook improves to the ability of all- students to participate in social and cultural in their new environment. The survey found that $46 \%$ college students used social media sites.

Junco, Merson \& Salter [11] found that Facebook allowed students to perform public political involvement. As a result, students who used Facebook more often for searching and sharing the data got higher marks than used it only to socialize. It proves that students who use Facebook for learning will influence positively.

Abdulahi, Samadi, and Gharleghi [12] found the negative effects of social networking sites such as Facebook toward University of Asia Pacific students in Malaysia. Negussie and Ketema [13] examined the correlation between the use of Facebook on academic achievement of 490 students in Jimma University. The results showed that there was no significant relationship between the using time and Facebook login frequency and GPA. Meanwhile Kamuh [14] tests the effect of social network on academic achievement of 100 IBA Program students at Manado's Sam Ratulangi University, and the results of which showed that there were simultaneously and partially social influences, spending time, and social lifestyle on academic performance.

Tamayo and Dela Cruz [15] examined the correlation of social media related to learning performance. The results showed no significant correlation between the social network and learning performance. A chew and [16] examined the use of social media by students and it's influences on students' academic performance of Koforidua Polytechnic, Ghana. The results 
showed that most respondents visited the websites of social media using mobile phones and spent around thirty minutes to three hours per day. In addition, the results of this study revealed that the use of social network sites has influenced the learning performance of students and there was a direct correlation between the use of social media sites and student learning performace.

Hasnain, Nasreen, and Ijaz [17] also examined the correlation between social media and student achievement. The results showed that there was correlation between social media and student learning performance. Amin, Mansoor, Hussain and Hashmat[18] conducted a study to find out the effect of the increasing use of social network sites related to the learning performance of college students. Results of the study showed that the influence of social media could be positive towards academic performance.

Tezer, Taşpolat, Rich \& Sapanca [19] found that social media and the internet use impact on the learning achievements in education. The results revealed that attitude of education students towards social media had an influence on academic achievement. Research of showed that the use of Facebook did not affect the learning performance of member of school.

Wan Othman, Mohd Apandi \& Ngah [20] found that there was a negative correlation between social media use and the academic performance of students. Social media has become a great phenomenon for generations $\mathrm{Y}$ and $\mathrm{Z}$, some of whom are in college. As one of the recent communication media, social media has helped them to communicate quickly and effectively. Shahibi \& Ku Rusli [21] showed that the online media also assisted students in improving their academic grade.

The development of scientific study occurs explosively where researchers conduct studies and produce as well as to favor the results of her empirical studies in various fields concerning the relationship between the variables of her interest. Furthermore, the result is often contradictory and confusing among investigators when trying to draw general conclusions from previous studies. A method for quantitative synthesis of research findings is a meta-analysis, which applies statistical techniques to summarize portions of empirical data in the research domain [22].

Therefore it can be emphasized that the aims of this research are to examine some research on social media and its effects on student academic grade by meta-analysis.

\section{Method}

\section{Data Sources}

Data is collected from, google scholar, Ebsco, Proquest, Dissertation Abstract, and Dissertation Abstract International. The used keywords are "social media", "Facebook ", "Instagram", "twitter", "learning achievement", "learning outcomes", "cumulative index". Because this research is to conduct an analysis using a quantitative metaanalysis approach, the user data are: (a) total $\mathrm{N}$, (b) value of correlation; r, F, or t, (c) if item b is not included, the manuscript must include the average score (M) and standard deviation (SD). Through these steps, 13 texts are obtained.

\section{Research Data Analysis Methods}

This study applies four stages of data analysis method: first, manage research data. Some researchers have been done regarding the relationship between social media and academic grade. They do not only examine one dimension of social media or only one academic grade. There are several dimensions that will be measured, and sometimes there are also different dimensions between one research with another even though the name of the variable is the 
same. In fact, there are also different variables, but with the same meaning, so that the coding is needed. Second, the coding is done by grouping variables that are meaningful to approach social media and learning outcomes. Third, for data which still contains F, t, or d values, it is first converted to $r$ values so that they are ready to be compared. Fourth, in this meta-analysis research just to find out the sampling error and the correction of the measurement error because those two corrections are artifacts that most pollute the results of research [23].

The steps in correcting sampling error can be done by estimating population $r$, weighted population $r$ variants, population $r$ variant of sampling errors and estimates of population $r$ variants. The steps are taken in correcting measurement errors by determining measurement errors on one variable or two variables at once, looking for instrument reliability, correction of measurement errors $\mathrm{x}$ and $\mathrm{y}$, average measurement errors on $\mathrm{x}$ and $\mathrm{y}$ until finally estimation of the population [24]

\section{Result and Discussion}

The results of the data selection consist of 13 independent variables and 13 variables dependent on 11 studies. Data that meets the requirements for analysis can be seen in table 1 .

Table 1. Tabulation of data research that meet the requirements for analysis.

\begin{tabular}{|c|c|c|c|c|c|c|c|}
\hline No & Research & $\begin{array}{l}\text { Independent } \\
\text { Variable } \\
\end{array}$ & $\begin{array}{l}\text { Dependent } \\
\text { Variable } \\
\end{array}$ & $\mathbf{N}$ & rxy & A & b \\
\hline 1 & $\begin{array}{l}\text { Negussie \& Ketema } \\
{[13]}\end{array}$ & $\begin{array}{l}\text { Times spend } \\
\text { on facebook }\end{array}$ & $\begin{array}{l}\text { Academic } \\
\text { Performance }\end{array}$ & 490 & 0,25 & 0,75 & 0 \\
\hline 2 & $\begin{array}{l}\text { Negussie \& Ketema } \\
{[13]}\end{array}$ & $\begin{array}{l}\text { Devices used } \\
\text { to login } \\
\text { facebook }\end{array}$ & $\begin{array}{l}\text { Academic } \\
\text { Performance }\end{array}$ & 490 & 0,31 & 0,83 & 0 \\
\hline 3 & $\begin{array}{l}\text { Abdulahi, Samadi \& } \\
\text { Gharleghi [12] }\end{array}$ & $\begin{array}{l}\text { Social } \\
\text { Network Site }\end{array}$ & $\begin{array}{l}\text { Academic } \\
\text { Performance }\end{array}$ & 152 & 0,34 & 0 & 0 \\
\hline 4 & Kamuh [25] & Social Media & $\begin{array}{l}\text { Academic } \\
\text { Performance }\end{array}$ & 100 & 0,95 & 0 & 0 \\
\hline 5 & $\begin{array}{l}\text { Tamayo \& dela } \\
\text { Cruz }[15]\end{array}$ & Social Media & $\begin{array}{l}\text { Academic } \\
\text { Performance }\end{array}$ & 138 & 0,69 & 0 & 0 \\
\hline 6 & $\begin{array}{l}\text { Acheaw \& Larson } \\
{[16]}\end{array}$ & Social Media & $\begin{array}{l}\text { Academic } \\
\text { Performance }\end{array}$ & 1508 & 0,75 & 0 & 0 \\
\hline 7 & $\begin{array}{l}\text { Hasnain, Nasreen, } \\
\text { Ijaz [17] }\end{array}$ & $\begin{array}{l}\text { Social Media } \\
\text { Usage }\end{array}$ & $\begin{array}{l}\text { Academic } \\
\text { Performance }\end{array}$ & 171 & $-0,2$ & 0 & 0 \\
\hline
\end{tabular}




\begin{tabular}{|c|c|c|c|c|c|c|c|}
\hline 8 & $\begin{array}{l}\text { Amin, Mansoor, } \\
\text { Hussain \& Hashmat } \\
{[18]}\end{array}$ & Facebook & $\begin{array}{l}\text { Academic } \\
\text { Performance }\end{array}$ & 290 & 0,3 & 0,7 & 0 \\
\hline 9 & $\begin{array}{l}\text { Amin, Mansoor, } \\
\text { Hussain \& Hashmat } \\
{[18]}\end{array}$ & Twitter & $\begin{array}{l}\text { Academic } \\
\text { Performance }\end{array}$ & 290 & 0,23 & 0,7 & 0 \\
\hline & & the purpose- & & & & & \\
\hline 10 & $\begin{array}{l}\text { Tezer, Taşpolat, } \\
\text { Kaya \& Sapanca } \\
{[19]}\end{array}$ & $\begin{array}{l}\text { frequency of } \\
\text { using social } \\
\text { media }\end{array}$ & $\begin{array}{l}\text { Academic } \\
\text { Performance }\end{array}$ & 204 & 0,16 & 0,84 & 0 \\
\hline 11 & Oyetunde [26] & Facebook & $\begin{array}{l}\text { Academic } \\
\text { Performance }\end{array}$ & 284 & $-0,3$ & 0 & 0 \\
\hline 12 & $\begin{array}{l}\text { Wan Othman, } \\
\text { Mohd Apandi, } \\
\text { Ngah [20] }\end{array}$ & $\begin{array}{l}\text { Social Media } \\
\text { Usage }\end{array}$ & $\begin{array}{l}\text { Academic } \\
\text { Performance }\end{array}$ & 200 & 0,08 & 0 & 0 \\
\hline 13 & $\begin{array}{l}\text { Shahibi \& Ku Rusli } \\
\text { [21] }\end{array}$ & Facebook & $\begin{array}{l}\text { Academic } \\
\text { Performance }\end{array}$ & 206 & 0,12 & 0 & 0 \\
\hline
\end{tabular}

The following are the correction results of sampling errors and measurement errors that test the relationship between social media and academic grade.

\section{Correction of sampling errors}

The calculation results of the correction artifact of sampling error, the relationship between social media and academic grade can be seen in table 2 .

Table 2. Calculation data summary of the correction artifact of sampling error.

\begin{tabular}{ll}
\hline Specification & Result \\
\hline Total sampel (N) & 4523 \\
Total r & 3.613 \\
Populationestimatesor mean r (r) & 0.385 \\
Variant correlation weighted population $\left(\mathrm{Sr}^{2}\right)$ & 0.11680
\end{tabular}




\begin{tabular}{ll} 
Correlation ofsamplingerrorvariance $\left(\mathrm{Se}^{2}\right)$ & 0.0028987 \\
Estimate ofthe populationvariancecorrelation $\left(\square \square \mathrm{r}^{2}\right)$ & 0.11390 \\
The impact of sampling error & $2.54 \%$ \\
\hline
\end{tabular}

As for the impact of sampling error of $2,54 \%$, this small percentage indicates the possibility of error bias due to errors in sampling is small.

\section{Correction of measurement errors}

The calculation results of correction artifacts of measurement error to test the relationship between social media and academic grade can be seen in table 3 .

Table 3. Calculation data summary of correction artifact of measurement errors.

\begin{tabular}{ll}
\hline Specification & Result \\
\hline Total Sample (N) & 4523 \\
Total study & 13 \\
Meanmeasurementerror (A) & 0,006143437 \\
Estimate ofthe population correlation( $\rho)$ & 62,67418492 \\
Total ofSquarescoefficientof variation (V) & 17,14760149 \\
Variationartifactsvariant (s 2 ) & 2,542164489 \\
Population correlationvarianceVar (r) & 0,06076 \\
Interval of confidence (r $\square \square$ & 0.1190896 \\
The impact of variations in the reliability & $-4086.0 \%$ \\
\hline
\end{tabular}

Based on the results of the confidence interval $(\mathrm{r} \rho)$ is $-4086.0 \%$ in which the results are greater than the impact of sampling errors, it can also show that the possibility of error bias due to errors on measurement is greater.

The meta-analysis results of the impact of sampling error in the relationship between social media and academic grades are $2,54 \%$ so that it can be concluded that the percentage of the other unidentified factors is $97,46 \%$. Furthermore, the findings from this meta-analysis reveal the bias possibility of the impact of reliability variations is greater. By conducting specification research in testing the effect of social media on academic grade, it was found that the hypothesis in which there was a relationship between social media and academic grade is acceptable.

Getting good academic grades is a dream of every student, parent, and educator after having the learning process. However, determining what causes students to achieve it is not an easy task to do especially in the technology era which has advantages and disadvantages.

Some research results show that social media has a negative effect and some have a positive effect on academic grade. Research which has found that there is a negative impact of social media on academic grade has argued that students cannot manage their time between learning and using social media, In addition, the use of it is extreme and wastes time and money, then it causes students to lose concentration on studying.

Moreover, social media also has a positive impact in student's academic grade such as a place for discussion to solve a problem [27]. However, on the other hand, social media had a 
negative effect on academic grade [28]. The most students believe that social media is a very useful tool in their learning. Thus, it can assist them to improve school-related activities. Thus, social media is expected to positively influence on academic grade of students. The interesting results illustrate that students mostly tend to use social network in a good way. These conditions can increase students' information and knowledge. In addition, social networks can enable students to discussion effectively to solve their class problems, as an effective tool used for communication about what they learn [29].

\section{Conclusion}

The correction artifact of sampling error to test the relationship between social media and academic grade indicates the possibility of error bias due to errors in sampling is small. The correction artifacts of measurement error to test the relationship between social media and academic grade show that the possibility of error bias due to errors on measurement is greater.

The limitation of this study is: First, meta-analysis research result is natural correlations and, therefore, cannot guarantee strong conclusions. Second, the overall result from the metaanalysis is often limited by the quality of the main research. Third, the influence of demographics such as gender, culture, the position of education level, the time of using social networks or media, the length of use and type of social media have not been specifically seen in this meta-analysis study. In fact, as the used time or the length of using social media is more being considered when it relates to academic grade.

The future study is expected to include the more strict criteria to ensure that other factors could be included such as how much time students are using social media sites and at what time they often use the social media site. In addition, by looking at the specifications, gender, culture or the broad criteria such as the type of social media, its effect on specific academic grades as well. Thus, the results of this study can be more specific clues for further research.

\section{References}

[1] I. Rowlands, D. Nicholas, P. Williams, P. Huntington, and M. Fieldhouse, "The Google generation: the information behaviour of theresearcher of the future," Aslib Proc. New Inf. Perspect., vol. 60, no. 4, pp. 290-310, 2008.

[2] S. Sudha and E. Kavitha, "The Effect of Social networking on Students' Academic Performance: the perspective of faculty members of Periyar University, Salem," Libr. Philos. Pract., p. 1455, 2016.

[3] A. M. Helou, "The Influence of Social Networking Sites on Students' Academic Performance in Malaysia," Int. J. Electron. Commer. Stud., vol. 5, no. 2, pp. 247-254, 2014, doi: doi: 10.7903/ijecs.1114.

[4] V. Raut and P. Patil, "Use of Social Media in Education: Positive and Negative impact on the students," Int. J. Recent Innov. Trends Comput. Commun., vol. 4, no. 1, 2016.

[5] A. M. Martínez Alemán and K. L. Wartman, Online social networking on campus: Understanding what matters in student culture. New York: Routledge, 2009.

[6] C. Madge and H. O'Connor, "On-line with e-mums: exploring the Internet as a medium for research," Area, vol. 34, no. 1, pp. 92-102, 2002.

[7] J. Pasek, E. More, and E. Hargittai, "Facebook and academic performance: Reconciling a media sensation with data," 2009.

[8] A. Lenhart, K. Purcell, A. Smith, and K. Zickuhr, "Pew internet: Social media in young adults," 2010. . 
[9] K. Kim, H. Yun, and Y. Yoon, "The Internet as a facilitator of cultural hybridization and interpersonal relationship management for Asian international students in South Korea," Asian J. Commun., vol. 19, no. 2, pp. 152-169, 2009.

[10] N. Lin, K. Cook, and R. Burt, "Building a network theory of social capital," in Social Capital: Theory and Research, New Brunswick, NJ: Transaction Publishers, 2001, pp. 3-29.

[11] R. Junco, D. Merson, and D. W. Salter, "The effect of gender, ethnicity, and income on college students use of communication technologies," CyberPsychology, Behav. Soc. Netw., vol. 13, no. 6, pp. 37-53, 2010.

[12] A. Abdulahi, B. Samadi, and B. Gharleghi, "A Study on the Negative Effects of Social Networking Sites Such as Facebook among Asia Pacific University Scholars in Malaysia," Int. J. Bus. Soc. Sci., vol. 5, no. 10, pp. 133-145, 2014.

[13] N. Negussie and G. Ketema, "Relationship between Facebook Practice and Academic Performance of University Students," Asian J. Humanit. Soc. Sci., vol. 2, no. 2, pp. 31-37, 2014.

[14] D. Kamuh, "The Impact of Social Media on Student Academic Performance of International Business Administration Program In Sam Ratulangi University Manado," J. EMBA, vol. 2, no. 3, pp. 1010-1018, 2014.

[15] J. D. Tamayo and G. S. G. dela Cruz, "The Relationship of Social Mediawith the Academic Performance of Bachelor of Science in Information Technology Students of Centro Escolar University-Malolos,” Int. J. Sci. Res. Publ., 2014.

[16] M. O. Acheaw and A. G. Larson, "Use of Social Media and its Impact on Academic Performance of Tertiary Institution Students: A Study of Students of Koforidua Polytechnic, Ghana," J. Educ. Pract., vol. 6, no. 6, pp. 94-101, 2015.

[17] H. Hasnain, A. Nasreen, and H. Ijaz, "Impact of Social Media Usage on Academic Performance of University Students," 2nd Int. Res. Manag. Innov. Conf. (Irmic 2015) Langkawi, 26-27 August 2015, 2015.

[18] Z. Amin, A. Mansoor, S. R. Hussain, and F. Hashmat, "Impact of Social Media of Student's Academic Performance," nternational J. Bus. Manag. Invent., vol. 5, no. 4, pp. 22-29, 2016.

[19] M. Tezer, A. Taşpolat, O. S. Kaya, and H. F. Sapanca, "The Impact of Using Social Media on Academic Achievement And Attitudes Of Prospective Teachers," Int. J. Cogn. Res. Sci. Eng. Educ., vol. 5, no. 2, pp. 75-81, 2017.

[20] W. R. Wan Othman, Z. F. Mohd Apandi, and N. H. Ngah, "Impact of Social Media Usage on Students Academic Performance in Terengganu, Malaysia," J. Appl. Environ. Biol. Sci., vol. 7, no. 5, pp. 140-144, 2017.

[21] M. S. Shahibi and K. N. K. Rusli, "The Influence of Internet Usage on Student's Academic Performance," Int. J. Acad. Res. Bus. Soc. Sci. 2017, vol. 7, no. 8, pp. 873887, 2017.

[22] A. Kock, "A Guide to Meta Analysis". TIM Working Paper, vol. 2. Berlin: Technische Universität Berlin, 2002.

[23] J. E. Hunter and F. L. Schmidt, Methods of Meta-Analysis: Correcting Error and Bias in Research Findings. Thousand Oaks, CA: Sage, 2004.

[24] M. N. Ghufron, "Apakah Religiusitas Berpengaruh Terhadap Kesuksesan Akademik? Studi Meta Analisis," in Proceeding Annual International Conference on Islamic Studies (AICIS) ke-13 IAIN Mataram 18-21 November 2013), 2013, pp. 465-480.

[25] D. Kamuh, "The Impact of Social Media on Student Academic Performance of International Business Administration Program In Sam Ratulangi University Manado," 
J. EMBA, vol. 2, no. 3, pp. 1010-1018, 2014.

[26] J. O. Oyetunde, "Influence of Facebooking and Social Media Use on Academic Performance among Nigerian Undergraduate Social Sciences Students," in Tesis and Dissertation, 2017.

[27] T. Heffner, "The effects of social media use in undergraduate students," in Theses and Dissertations. 1440, 2016.

[28] Q. Wang, W. Chen, and Y. Liang, "'The Effects of Social Media on College Students". MBA Student Scholarship. Paper 5. .," 2011.

[29] A. Benraghda and N. R. M. Radzuan, "Engineering undergraduates' self-assessment in delivering technical oral presentations in ESL context," $A d v$. Sci. Lett., vol. 24, no. 1, pp. 537-539, 2018. 